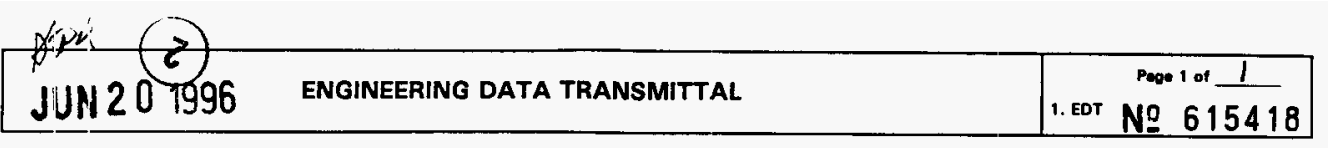

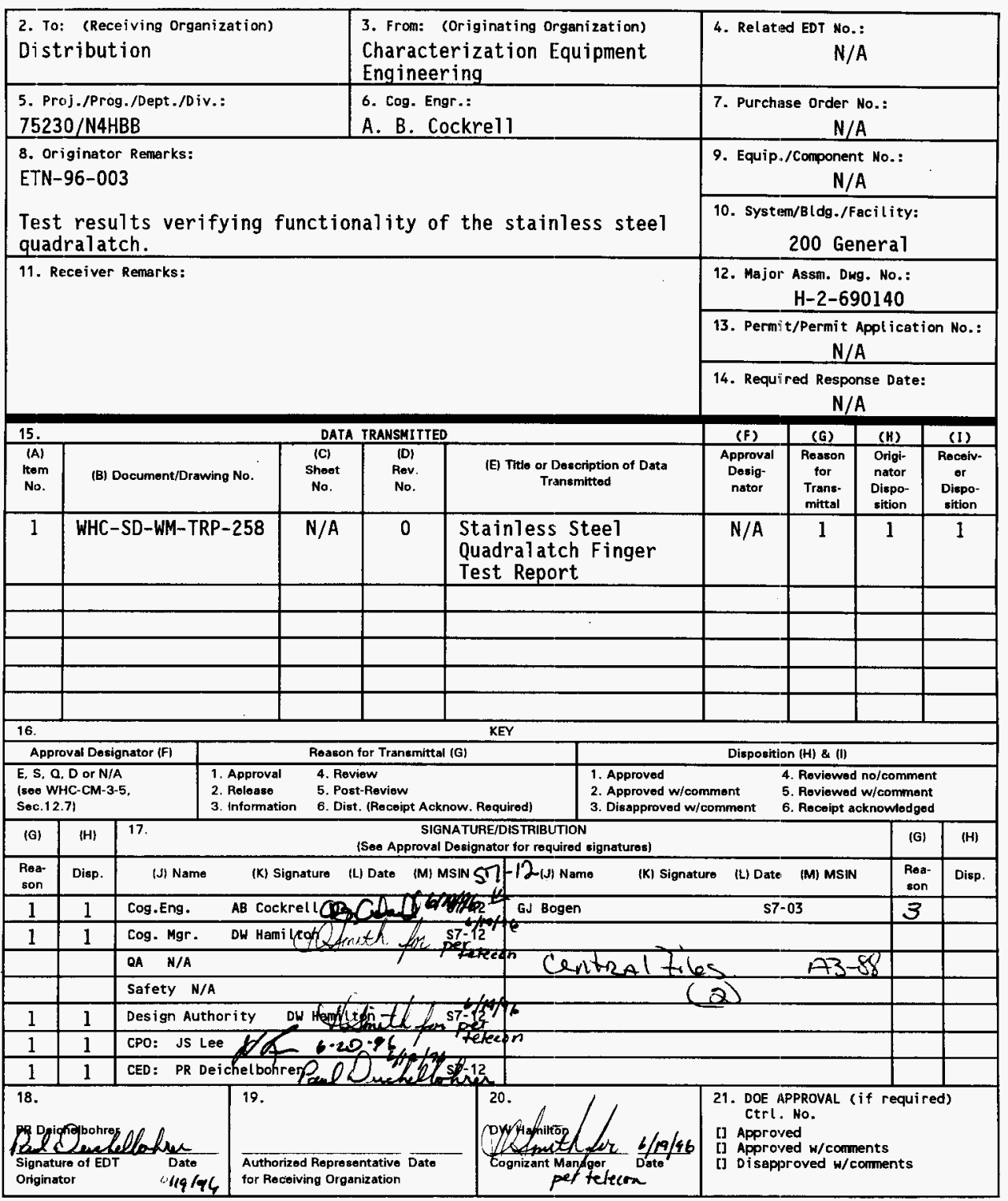




\title{
STAINLESS STEEL QUADRALATCH FINGER TEST REPORT
}

\author{
P. R. Deichelbohrer \\ Westinghouse Hanford Company, Richland, WA 99352 \\ U.S. Department of Energy Contract DE-AC06-87RL10930 \\ EDT/ECN: $615418 \quad$ UC: \\ Org Code: 75230 Charge Code: N4HBB \\ B\&R Code: \\ UC: \\ Total Pages: $14 / 3 \mathrm{~km} / / 2 . / 96$
}

Key Words: Sampler, core barrel, test fixture, upward force

Abstract: The design of the quadralatch on the universal samplers was changed in response to flammable gas operating constraints. Additional redesign of the fingers was included to facilitate manufacturability.

The new design was tested to assure satisfactory performance. It was shown that the fingers can hold a sampler in place with an upward force of at least $2200 \mathrm{~N}$ (500 pounds) and that the mechanical remote latch unit can release the quadralatch under this condition of maximum upward force.

TRADEMARK DISCLAIMER. Reference herein to any specific comercial product, process, or service by trade name, trademark, manufacturer, or otherwise, does not necessarily constitute or imply its endorsement, recommendation, or favoring by the United States Government or any agency thereof or its contractors or subcontractors.

Printed in the United States of America. To obtain copies of this docunent, contact: WHC/BCS Document Control Services, P.O. Box 1970, Mailstop H6.08, Richland HA 99352, Phone (509) 372-2420; Fax (509) 376-4989.
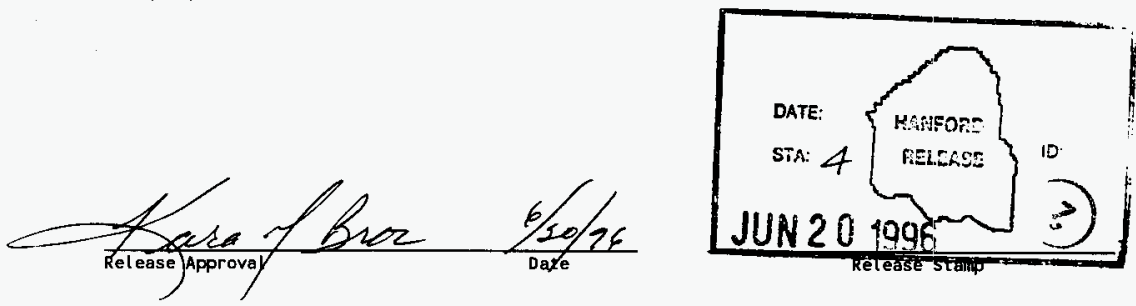

Approved for Public Release 
STAINLESS STEEL QUADRALATCH FINGER

TEST REPORT

\author{
WHC-SD-WM-TRP-258 \\ REVISION 0
}

Prepared by:

P. R. Deichelbohrer

June 19,1996 
WHC-SD-WM-TRP-258

Revision 0

Page 2 of 12

Table of Contents

1.0 Introduction . . . . . . . . . . . . . 3

2.0 Background .................... 3

3.0 Description of the Test ................ 7

4.0 Performance Criteria .............. 7

5.0 Test Results . . . . . . . . . . . . . . . . . 8

6.0 Conclusions and Recommendations ............. 9

7.0 Disposition of Test Item ............... 9

8.0 References . . . . . . . . . . . . . . . 9

9.0 Appendix A................... 9 
WHC--SD-WM-TRP-258

Revision 0

Page 3 of 12

\section{STAINLESS STEEL QUADRALATCH FINGER TEST REPORT}

\subsection{Introduction}

Stainless steel quadralatch fingers were tested by Characterization Equipment Design (CED) under Cost Account N4HBB. Production Control/Maintenance supported the effort by fabricating test fixtures. Fabrication Control, Kaiser Hanford, fabricated the test fingers under Work Order C18989.

Testing was performed in accordance with Test Procedure WHC-SD-WN-TP-487 on June 11 and 12, 1996. Some preliminary testing was performed beginning May 15, 1996.

\subsection{Background}

The quadralatch is a four-fingered device attached to the top of a core sampler to hold it in the core barrel during sampling and to interface to the Remote Latch Unit (RLU) for handling (Figure 1). The four fingers, and four springs are bolted to the square quadralatch head base. The fingers are pushed outward by the springs to actuate the lower barbs into grooves in the core barrel--during sampling. The upper barbs mate to a ledge in the RLU for supporting the sampler during installation. The taper at the top of the fingers is used by the release cone (part of the RLU) to compress the fingers to release it from the RLU.

As explained in the Test Plan (Reference 8.1), stainless steel quadralatch fingers are expected to be less likely to generate frictional sparks than the old carbon steel fingers which is an important consideration for sampling in flammable gas tanks.

The original quadralatch fingers were purchased from by Boyle Brothers Drilling. They were modified on-site for optimum performance in drilling/sampling operations. The lower barb was reduced in size, the upper barb was finish-cut, and an unused mass, located below the lower barb, was removed. These modifications were made after the fingers were assembled to the quadralatch assembly (Reference H-2-85097). It should be observed that, in its final form, the quadralatch is not well suited for machining. Consequently, special tooling was obtained (accurate 4-jaw chuck, taper mandrel, and 2 rings) to $j$ ig the quadralatch assembly during final machining. This tooling interfaced to the internal taper on the fingers (see Figure 1) and the flats on the head base.

The original finger manufacturers do not supply fingers of stainless steel. Furthermore, fabrication by investment casting would be cost effective. Also, minimizing the amount of finish-machining would be desirable. As a result, the fingers were redesigned (Figure 2). The new design is smaller than the old-narrower and omitting the unused mass below the lower barb. Also, the lower barb is more-exposed which is expected to enhance engagement in the core barrel. Also, the finger tips are thinner to provide added clearance for the 
WHC--SD-WM-TRP-258

Revision 0

Page 4 of 12

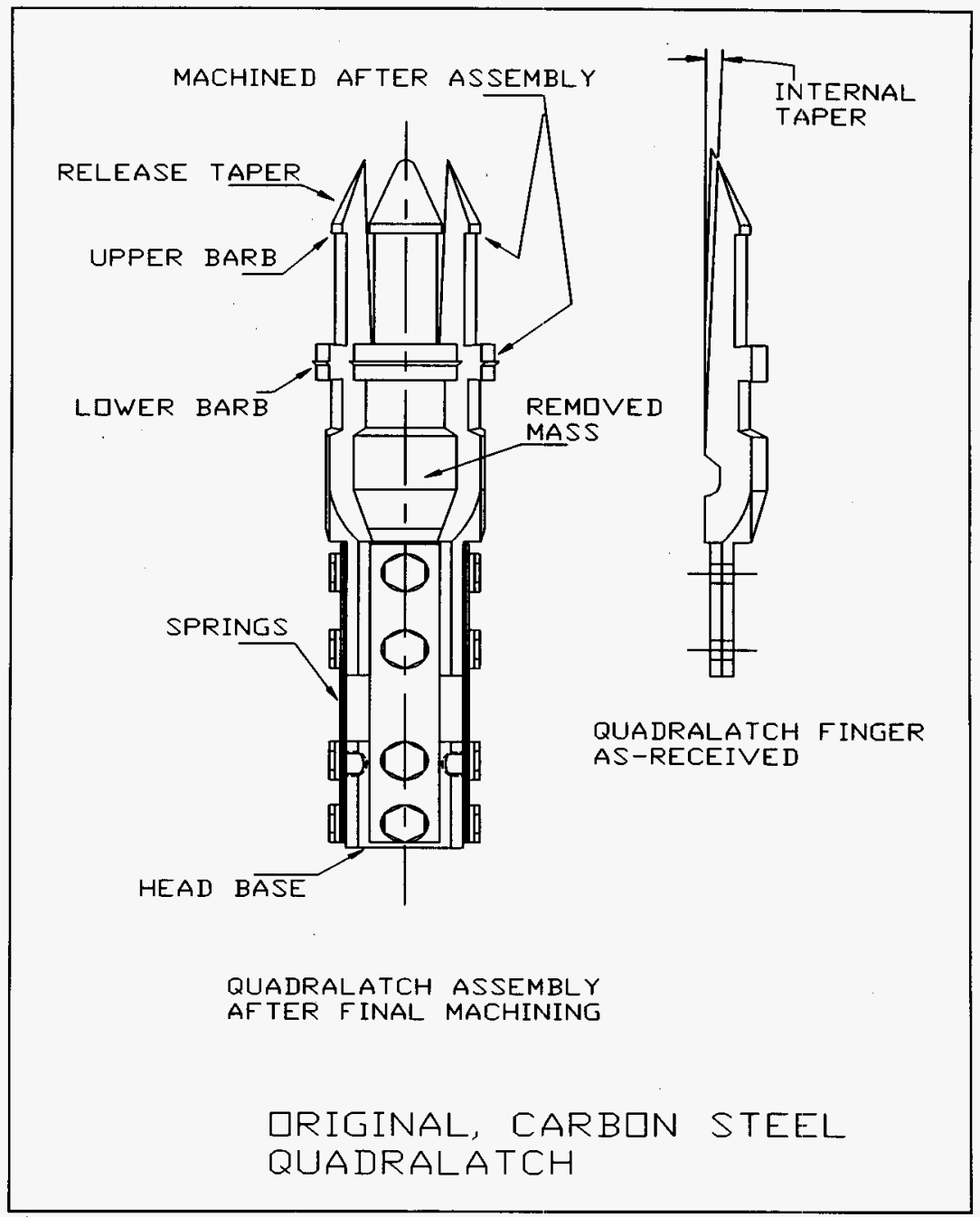

Figure 1 QUADRALATCH AND FINGER 
WHC-SD-WM-TRP-258

Revision 0

Page 5 of 12

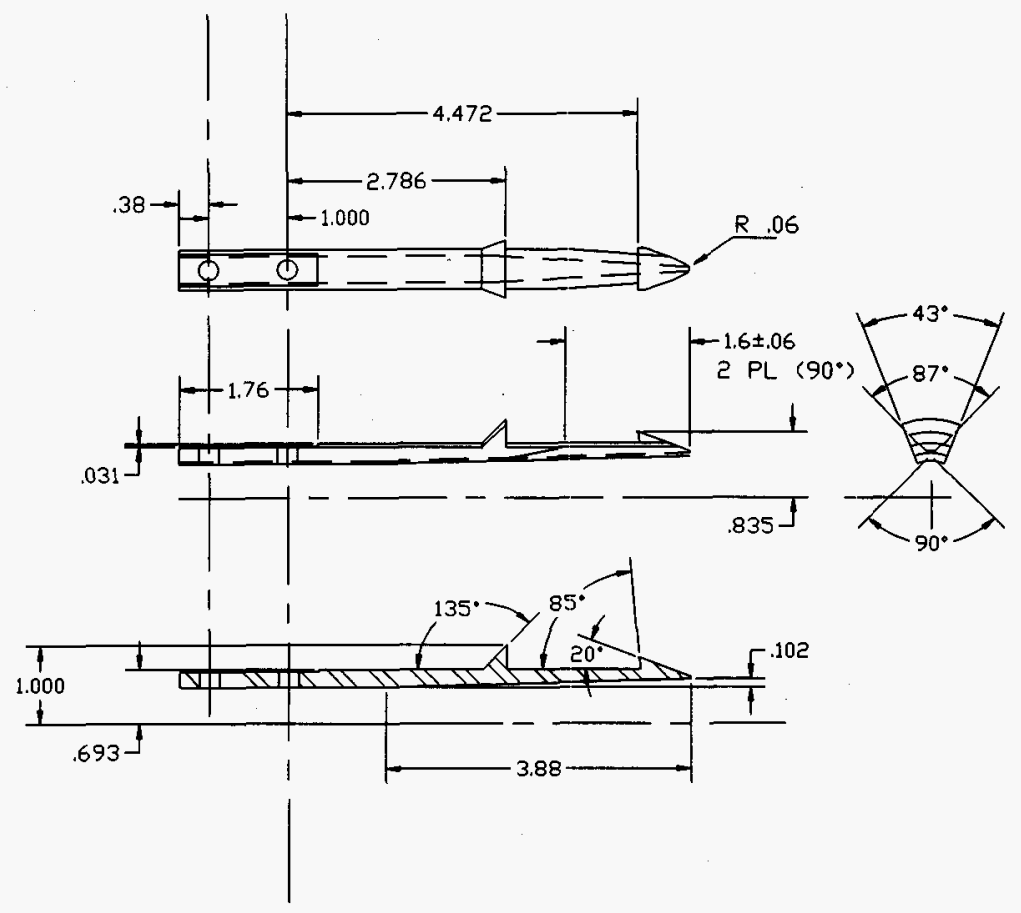

STAINLESS STEEL

QUADRALATCH FINGERS

MAY 21, 1996

TAPER,DWG

Figure 2 Stainless Steel Quadralatch Finger

pintel rod in the sampler when it is empty. The internal taper is cylindrical which is expected to improve the stability of the quadralatch components during finish machining.

The new fingers are made of 300-series stainless steel which is somewhat softer that the old fingers. It is intended that the fingers are softer than the material in the core barrel since each quadralatch is used orly once while 
WHC-SD-WM-TRP-258

Revision 0

Page 6 of 12

the core barrel is used for 1-22 operations. In this way, wear-out at the core barrel-quadralatch interface will be concentrated on the throw-away part i.e., the quadralatch.

\subsection{Description of the Test}

A test fixture (see Figure 3) was built to apply upward force to a sampler and, thus, load the quadralatch. The upward force was measured with a General Electrodynamics, Model E10218 Static Wheel Weigher.

The sampler was inserted into the core barrel of the fixture and supported on a central rod which transmits force to the wheel weigher. The nuts on the "Allthread" were tightened with a wrench until the requisite force registered on the wheel weigher. Under these conditions the holding capacity of the fingers was verified. Since the finger tips are visible (near the core barrel opening) seating under load can be observed.

Operation of the stainless steel quadralatch fingers with the Mechanical RLU (which is also a new design in response to flammable gas requirements) was also tested. While the quadralatch is under load, loosening and lifting with the RLU was verified.

An earlier design of the stainless steel quadralatch fingers had been under consideration at the time the test fixture was fabricated. This version did not employ the internal tapers (Figure 2). Also, some of the fabrication tolerances were excessively loose. These, test, units demonstrated marginal reliability in the test fixture. In new, clean core barrels, they performed correctly, however, in rusted core barrels, was might be encountered in intank operations, the fingers would not hold the sampler in place, i.e., they released with 1-5 pounds force.

Consequently, the design was improved as shown in Figure 2.

Two sets of quadralatch fingers were manufactured. Care was taken to mill the mounting flats (see Figure 2) before the individual fingers were cut from the bar. Also, final machining was performed after the fingers were mounted to the base head. Thus, two complete quadralatches were delivered for testing. The test quadralatches featured stainless steel fingers, only. The remainder (springs, bolts, and head base) were of the original carbon steel.

A carbon steel quadralatch was selected from inventory for comparison testing. Two new core barrels were randomly selected from inventory for testing with the stainless steel quadralatches. Also, a rusty core barrel was available for testing the fingers under more extreme conditions. 
WHC-SD-WM-TRP-258

Revision 0

Page 7 of 12

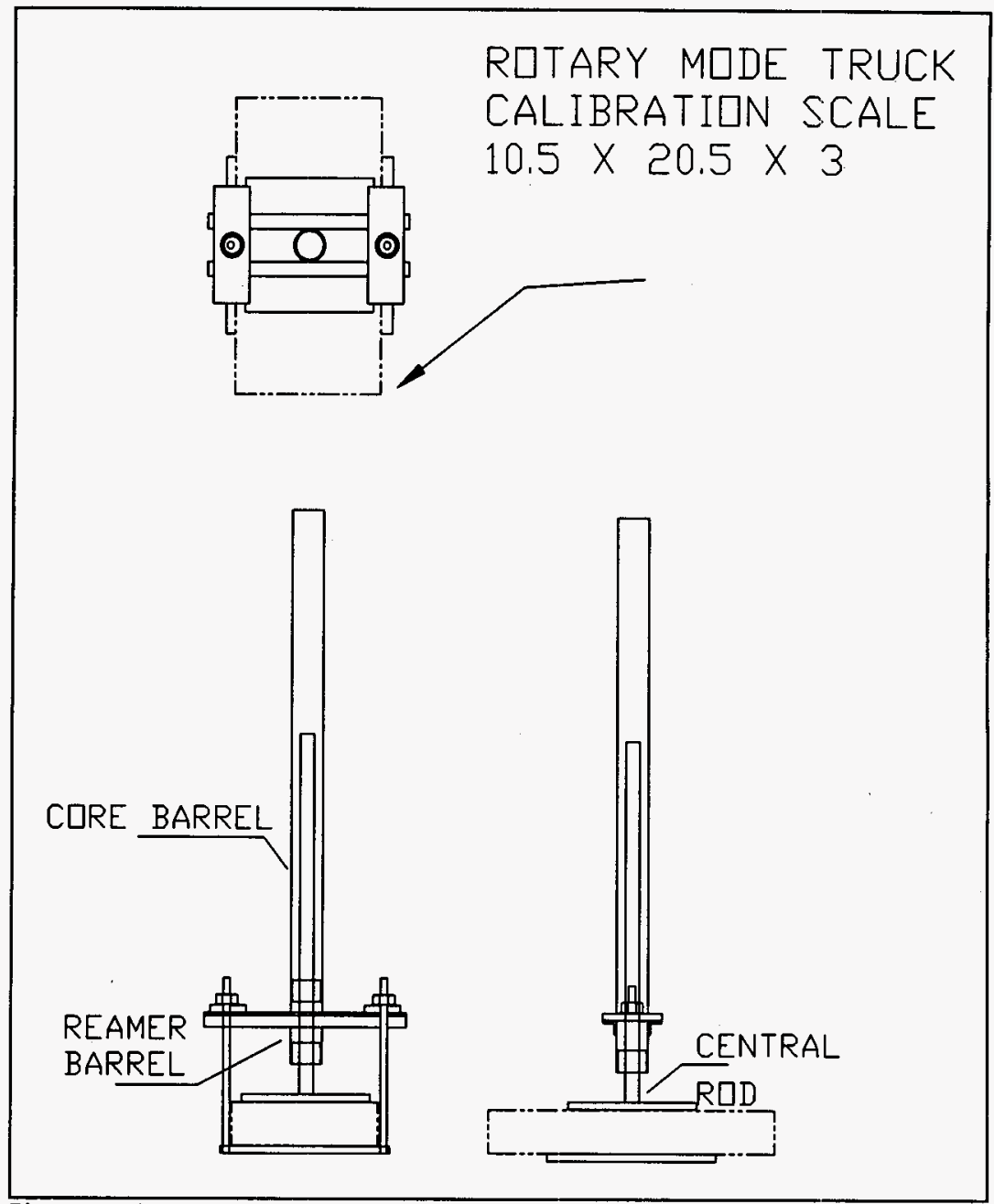

Figure 3 Test Fixture 
WHC-SD-WM-TRP-258

Revision 0

Page 8 of 12

\subsection{Performance Criteria}

The quadralatches were tested to the following performance criteria:

1) hold the sampler in $\mathrm{place}$ in the core barrel with minimum upward force of $2200 \mathrm{~N}$ (500 pounds).

2) be released from the core barrel by the RLU while under maximum upward force load

3) be released from the RLU

4) allow sufficient clearance for the pintel rod.

\subsection{Test Results}

The results of the test are tabulated on the Data Sheet and Exception Sheet in Appendix I.

The initial testing was performed in the rusty core barrel. One of the new, test specimens failed 2 out of 3 times. The other new unit easily passed the $2200 \mathrm{~N}$ (500 pound) load requirement and the unlatching requirement.

Unlatching testing was performed with a mechanical RLU and the three tungsten weights (16 $\mathrm{kg}$ ( 36 pounds), total). The quadralatch was readily released as the weight was allowed to be applied to the RLU. It is estimated that less than $66 \mathrm{~N}$ (15 lbs) was required to unlatch in all cases.

It was observed that unlatching, under load, damages the stainless steel fingers. This operation generates a burr on the lower edge of the latching barbs (lower barbs) by "rolling" some metal from the barb-core barrel interface. It is believed that the ductility of the 300-series stainless steel used contributes to this phenomenon.

The quadralatch fingers were returned to the shop where the burrs were removed (filed off). Further unlatching testing was not carried out. Unlatching test results on-hand were sufficient to confirm satisfactory operation.

The machinist who fabricated the fingers pointed out that the fingers on specimen \#l were insufficiently spread out. This, he claimed, would explain its failure to perform in the test fixture. The machinist corrected the outspring condition and checked it with a ring gage that is called out in the design drawing $\mathrm{H}-2-85097$.

After the fingers were returned from the shop, they were designated: $I R$ and $2 R$. As can be seen in the Data Sheets, specimen $1 R$ performed better than $2 R$. Examination of $2 R$ indicated that it had been bent, and shifted in its mount bolt holes, by the previous-days testing. In the Data Sheet, it can be seen that specimen 2 had been tested to $2600 \mathrm{~N}$ ( 600 pounds), previously. Presumably, this large force distorted/bent the fingers and lead to the units, subsequent, decreased latching capacity. 
WHC-SD-WM-TRP-258

Revision 0

Page 9 of 12

After testing with the rusty core barrel, testing on two, new core barrels was performed. As can be seen in the Data Sheets, all units demonstrated 500 or more pounds of latching capacity. In other words, all of the test specimens passed the test requirements when used with new core barrels.

At then end of the testing, an old carbon steel quadralatch was installed in a new core barrel and tested to destruction. The quadra 7 atch-core barrel failed at 1500 pounds. It was observed that the failure was in the core barrel. One of the grooves had been torn loose. No damage was observed on the carbon steel quadralatch fingers. This test tends to substantiate the choice of softer, 300-series stainless steel for the quadralatch fingers.

\subsection{Conclusions and Recommendations}

For optimum performance, the stainless steel quadralatch finger have to be finish-machined after mounting to the quadralatch sub-assembly. Furthermore, the fingers should be pushed downward, against their mounting bolts, before the bolts are tightened and the final turning is performed.

It appears that the stainless steel quadralatch fingers are a one-use item. If in operation, the unlatching is performed while the fingers are under load, the fingers may be damaged. This damage (a burr rolled on to the lower lip of the latching barb) will probably reduce subsequent latching force capacity of the quadralatch. This property is not expected to impact the current use practices of the quadralatches/samplers.

The improved design stainless steel quadralatch fingers (Figure 2) were shown to perform satisfactorily. The force to pop-out the old carbon steel quadralatch fingers seems to be higher than the stainless steels ones. However, this could lead to damage to the core barrel under adverse conditions.

It is recommended that the stainless steel quadralatch finger design (Figure 2) be incorporated into the universal sampler design drawing. It is further recommended that the fingers be "bottomed-out" against their mounting bolts before final machining. Also, the fingers have to be sprung-out after machining to fulfill the "ring" acceptance criteria in drawing $\mathrm{H}-2-85097$, sheet 7 , zone $\mathrm{D}-4$.

Utilization of investment casting in the manufacturing process is also recommended.

\subsection{Disposition of Test Item}

The test stainless steel quadralatch fingers as well as the carbon steel test quadralatch fingers will be archived for further reference. The testing equipment will be available for, possible, future quadralatch testing. 
WHC-SD-WM-TRP-258

Revision 0

Page 10 of 12

\subsection{References}

WHC-SD-WM-TP-487 Stainless Stee] Quadralatch Testing

$\mathrm{H}-2-85097$

$\mathrm{H}-2-690140$ Universal Sampler

Core Sampler Assembly 
WHC-SD-WM-TP-487

Rev. 0

Page 10 of 11

TEST DATA SHEET

STAINLESS STEEL QUADRALATCH FINGERS

\begin{tabular}{|c|c|c|c|c|c|}
\hline Date & Specimen & $\begin{array}{l}\text { Core } \\
\text { Barrel } \\
\end{array}$ & $\begin{array}{l}\text { Latching } \\
\text { Force }\end{array}$ & Unlatching & Comment \\
\hline $6 / 11$ & Cantom & Runty & $500 \mathrm{llhe}$ & ok & contral \\
\hline$"$ & -1 & $1 \%$ & 180 & & Poppeal ant \\
\hline$"$ & $\notin 1$ & $"$ & 500 & $0 k$ & pareed \\
\hline$"$ & $\# 1$ & " & 200 & & poppeal out \\
\hline$"$ & $x_{2}$ & $"$ & 500 & ok & paced \\
\hline " & 2 & $"$ & 500 & OK & pased \\
\hline$"$ & 2 & " & 600 & oik & pasend \\
\hline & se & discuses & $m$ en $\varepsilon_{n u}$ & eption sheet & \\
\hline $6 / 12$ & Canters stad & Runty & $5=0 \mathrm{et}$ & & contral \\
\hline ". & $2 R$ & ." & 310 & ok & Papped and rest \\
\hline " & $2 R$ & ". & 520 & & papperl aut \\
\hline ', & $I R$ & " & 540 & & paseud 'stay el latoled) \\
\hline$"$ & aibental & $\begin{array}{l}\text { new wal cons } \\
\text { Barear } \\
1\end{array}$ & 600 & & centrel \\
\hline "' & IR & ". & 630 & & staged lateruel \\
\hline$"$ & $2 R$ & "' & 720 & & $\ldots$ \\
\hline 10 & Sanhonsetel & $\begin{array}{c}\text { New } \\
\pm 2 \\
\end{array}$ & 560 & & cantre 2 \\
\hline ". & $2 R$ & " & 600 & & stayed lat thal \\
\hline. & $1 R$ & $"$ & 600 & & . . \\
\hline $6 / 12$ & $\begin{array}{l}\text { couton } \\
\text { steal }\end{array}$ & $\begin{array}{l}\text { NeW CuRE } \\
\text { BoRear } 4\end{array}$ & 1500 & \multicolumn{2}{|c|}{ 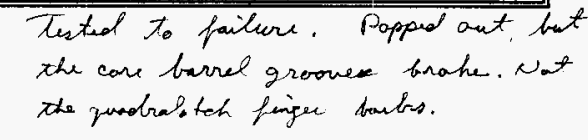 } \\
\hline
\end{tabular}

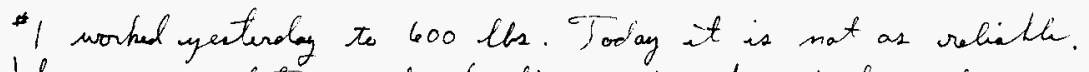
It oppears that one of the fingers has heen bent. Also, the latching barbs are not in a plave (est. 0.01 meelagrual.) 7 mast likely yusterdays tucting shiftel the firgers in their bolt holes and probubly hent them. 
Appendix B

$$
\begin{aligned}
& \text { WHC-SD-WM-TRP-258, Rev. } 0 \\
& \text { Page } 12 \text { of } 12 \\
& \text { WHC-SD-WM-TP-487 } \\
& \text { Rev. } 0 \\
& \text { Page } 11 \text { of } 11
\end{aligned}
$$

EXCEPTION SHEET

STAINLESS STEEL QUADRALATCH FINGERS

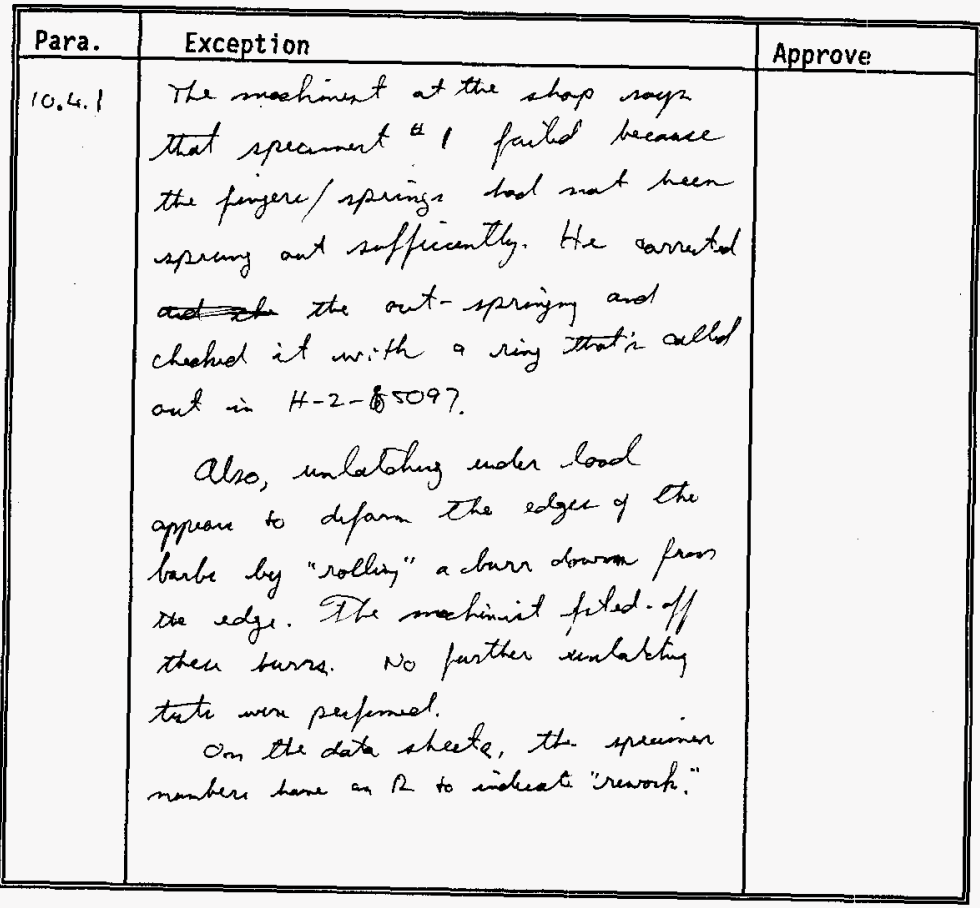

